\title{
PHẪU THUẬT NộI SOI 3D THAY VAN BA LÁ Ở BỆNH NHÂN MỔ CŨ THAY VAN HAI LÁ: THÔNG BÁOCA LẦM SÀNG
}

Nguyễn Anh Huy*,Nguyễn Công Hưu**, Đoàn Văn Nghĩa*, Ngô Thành Hung**, Lương Thị Nhu Huyền **, Nguyễn Thế Bình**, Nguyễn Trung Hiếu**, Phạm Tuấn Anh**, Lê Ngọc Thành**

\section{TÓM TẮT}

Thông báo ca lâm sàng bệnh nhân hở van ba lá nặng, suy tim ở bệnh nhân có tiền sử mổ cũ thay van hai lá cơ học, rung nhĩ đã được phẫu thuật nội soi (sử dụng hệ thống nội soi 3D) qua đường mở nhỏ ngực phải 3D thay van ba lá sinh học tại Trung tâm Tim mạch bệnh viện E. Thông báo đề cập đến chỉ định, kỹ thuật và nguy cơ phẫu thuật thay van ba lá nội soi qua đường mở nhỏ ngực phải ở bệnh nhân đã phẫu thuật van hai lá trước đó.

Tù khóa: phẫu thuật nội soi, tim đập

3D ENDOSCOPIC REDO TRICUSPID VALVE REPLACEMENT IN A PATIENT AFTER MITRAL VALVE SURGERY:

\section{SUMMARY}

\section{A CASE REPORT}

This case report describes a patient with severe tricuspid valve regurgitation, atrial fibrillation, heart failure and history of mechanical mitral valve replacement, was diagnosed and treated by 3D endoscopic redo biological tricuspid valve replacement in Cardiac Center- E hospital. Furthermore, we will discuss surgical technique and summarize published information about this procedure.

Keywords: endoscopic, beating heart

\section{I. ĐặT VẤN ĐỀ}

Điều trị phẫu thuật van ba lá cho những trường hợp hở van nhiều sau mổ thay van hai lá nhân tạo vẫn còn nhiều tranh cãi. Phẫu thuật van ba lá chủ yếu là sửa van do thay van ba lá có tỷ lệ bị huyết khối van tim cao hơn ở các vị trí van khác [1]. Tuy nhiên, trong một số trường hợp,lựa chọn thay van được đặt ra cho những bệnh nhân van tim thương tổn thực thể không có khả năng bảo tồn. Phẫu thuật nội soi thay van ba lá ở bệnh nhân mổ cũ đã được công bố với những ưu điểm nhất định, giảm tỷ lệ tử vong[2]. Tại Việt Nam cho đến nay chưa có thông báo nào về phương pháp phẫu thuật này.

Mục tiêu thông báo lâm sàng đề cập đến chỉ định, kỹ thuật thay van ba lá nội soi qua đường mở nhỏ ngực phải ở bệnh nhân đã phẫu thuật van hai lá trước đó.

\section{GIỚI THIÊUU CA LÂM SÀNG}

Bệnh nhân nữ, 73 tuổi, tiền sử: phẫu thuật thay van hai lá cơ học năm 2010 Tại trung tâm tim mạch bệnh viện E. Sau mổ bệnh nhân điều trị nội khoa thường xuyên. Đợt bệnh này, bệnh nhân khó thở và phù khoảng 1 tuần. Khám vào viện: bệnh nhân tỉnh, thể trạng gầy (BMI 10,2), phù toàn thân, khó thở NYHA III - IV, phổi nhiều ran ẩm 2 bên, tim loạn nhịp hoàn toàn, bụng chướng dịch, gan to $4 \mathrm{~cm}$ dưới bờ sườn, tiểu ít. Bệnh nhân được xử trí cấp cứu: Thở $\mathrm{O} 2$ kính, lợi tiểu tĩnh mạch, chống đông, đặt các đường truyền trung ương và theo dõi tại đơn vị hồi sức.

Siêu âm tim trước mổ: Van hai lá cơ học đúng vị trí, hoạt động được, hở nhẹ van động mạch chủ. Van ba lá hở nhiều, nhĩ trái giãn lớn (68mm-71mm), $\mathrm{S}$ hở ba lá chiếm toàn bộ nhĩ phải $(40 \mathrm{~cm} 2)$. ĐK vòng van $40 \mathrm{~mm}$. EF\% 68\%. Tràn dịch màng phổi phải.

Bệnh nhân đã được chỉ định phẫu thuật với chẩn đoán: Hở van ba lá nặng/ Mổ cũ thay van hai lá cơ học, suy tim, rung nhĩ. Phẫu thuật ngày 17/05/2019.

\section{Cách thức phẫu thuật:}

+ Tư thế bệnh nhân trong mổ: Nghiêng trái 30 độ, hai tay khép dọc thân, đầu bệnh nhân đặt

\footnotetext{
* Truò̀ng đại học Y Hà Nội

** Trung tâm Tim mạch Bệnh viện E

Ngưòi chịu trách nhiệm khoa họ: BS Nguyễn Anh Huy

Ngày nhận bài: 01/11/2019 - Ngày Cho Phép Đăng: 20/12/2019

Phản Biện Khoa học: PGS.TS. Đặng Ngocc Hùng
}

GS.TS. Lê Ngoc Thành 
nghiêng trái bộc lộ vùng cổ phải cho đặt ống tĩnh mạch chủ trên qua da. Đặt bản điện cực chống rung ngoài hai bên xương bả vai.

+ Thiết lập hệ thống tuần hoàn ngoài cơ thể: Đặt ống động mạch vào động mạch đùi chung phải gián tiếp qua đoạn mạch Dacron số 6 , đặt ống tĩnh mạch vào tĩnh mạch đùi phải và tĩnh mạch chủ trên qua da từ tĩnh mạch cảnh trong phải.

+ Đường tiếp cận: Mở ngực nhỏ $5 \mathrm{~cm}$ vị trí đường trước bên phải KLS IV cho cổng phẫu thuật chính, 01 trocart $10 \mathrm{~mm}$ vị trí KLS IV đường nách giữa đặt ống kính nội soi $3 \mathrm{D}, 01$ trocart $5 \mathrm{~mm}$ vị trí KLS III đường nách giữa cho tay phẫu thuật thứ hai.

+ Bảo vệ cơ tim: Để tim đập ở nhiệt độ cơ thể, không cặp động mạch chủ.

\section{phẫu thuật:}

Mô tả tổn thương và các bước trong

Phổi dính nhiều vào thành ngực, gỡ dính phổi bộc lộ màng tim. Mở màng tim, gỡ dính tối thiểu vị trí nhĩ phải (nhĩ phải thành mỏng). Bơm $\mathrm{CO} 2$ vào khoang màng phổi. Phẫu tích đặt dây thắt tĩnh mạch chủ trên, không thắt tĩnh mạch chủ dưới; tim đập, không cặp động mạch chủ. Mở dọc nhĩ phải: buồng nhĩ phải giãn rất lớn, van ba lá tổn thương thực thể: lá van co rút nặng gây thiếu nhu mô van, vòng van giãn lớn.

Thay van SJ sinh học số 33 (để lại toàn bộ nhu mô van), chỉ dệt số $2 / 0$ có miếng đệm, mũi chữ U.Đóng nhĩ phảipremilen $5 / 0$ vắt. Đóng màng tim, ngừng máy tim phổi nhân tạo, rút các ống, cầm máu, đặt dẫn lưu khoang màng phổi phải. Đóng lại các vết mổ theo các lớp giải phẫu. Tổng thời gian chạy tuần hoàn ngoài cơ thể là 160 phút. Tổng thời gian phẫu thuật là 300 phút.

\section{Diễn biến hậu phẫu:}

Bệnh nhânthở máy ngày thứ 5 , diễn biến huyết động ổn định, dẫn lưu những ngày đầu ra ít máu loãng, ngày thứ 4 thứ 5 xuất hiện ra máu cục. X- quang ngực tại giường hình ảnh mờ toàn bộ trường phổi trái, siêu âm tại giường có máu cục màng phổi.

Bệnh nhân được chỉ định phẫu thuật nội soi mở ngực ngày 22/05/2019. Kiểm tra trong mổ: khoang màng phổi nhiều máu cục và nước máu (600gr máu cục và $500 \mathrm{ml}$ nước máu cũ), không có điểm chảy máu lớn. Tiến hành lấy máu cục và nước máu nội soi, làm sạch khoang màng phổi.

Sau mổ lần 2 bệnh nhân tỉnh, thở máy hỗ trợ (CPAP) trong 9 ngày, được rút dẫn lưu màng phổi sau 5 ngày, duy trì 1 vận mạch liều thấp, kháng sinh. Các thông số về lâm sàng huyết động, khí máu ổn định sau 2 tuần.

Siêu âm tim sau mổ: van ba lá nhân tạo sinh học hoạt động tốt, chênh áp qua van ba lá trung bình $5 \mathrm{mmHg}$, tối đa $11 \mathrm{mmHg}$, EF $67 \%$, nhĩ trái $68 \mathrm{~mm}$, đường kính thất phải $19 \mathrm{~mm}$.

Một số thông số khác sau mổ: BMI 14,6, không phù, không loét, các xét nghiệm về chức năng gan, thận, đường máu trong giới hạn bình thường.

Bệnh nhân được chuyển lên bệnh phòng ngày thứ 31 , tình trạng lâm sàng ổn định đến trước khi dự kiến ra viện 3 ngày ， bệnh nhân xuất hiện sốt cao liên tục, cấy máu có kết quả dương tính với tụ cầu vàng. Trong quá trình hồi sức bệnh nhân xuất hiện tai biến mạch não ( xuất huyết não ), tình trạng nặng và xin về tại đơn vị hồi sức.

\section{BÀN LUẬn}

Phẫu thuật nội soi đã trở thành phẫu thuật thường quy cho những trường hợp thay van hai lá hoặc van ba lá nguyên phát [3]. Đây là phương pháp ít xâm lấn, an toàn, tỷ lệ tử vong sau mổ thấp. So với phẫu thuật truyền thống thì phương pháp này có ưu điểm vết mổ nhỏ, nhanh liền sẹo, có tính thẩm mỹ cao, ít đau hơn, không phải cưa xương ức nên tránh được các nguy cơ chảy máu, nhiễm trùng, khớp giả xương ức sau mổ [4]. Nhiều tác giả trên thế giới cũng đã sử dụng phương pháp và ứng dụng trong những trường hợp phẫu thuật lại ở những bệnh nhân đã có phẫu thuật tim trước đó. Họ đã chứng minh lợi ích của phương pháp này. Những lợi ích thiết thực của nó là: tránh tái lập việc cưa xương ức, hạn chế gỡ dính tim, giảm nguy cơ truyền máu, giảm biến 
chứng vết thương, giảm tỷ lệ mắc bệnh và giảm thời gian nằm viện [5].

Phẫu thuật mổ mở ở bệnh nhân đã có thay van trước đócó những nguy cơ nguy hiểm nhất định. Bettina Pfannmuller đã đề cập đến một số nguy cơ, trong đó 2 nguy cơ lớn nhất của phẫu thuật này là: (1) Cưa xương ức là một chấn thương lớn của phẫu thuật, (2) việc gỡ dính nhiều ở những tổ chức mỏng như nhĩ phải và phì đại tâm thất phải do suy tim là việc làm phức tạp và nguy cơ chảy máu cao [6].

Tổn thương dẫn truyền là một trong những nguy cơ lớn của phẫu thuật thay van ba lá.Nút xoang nhĩ rất dễ bị tổn thương trong quá trình đặt ống tĩnh mạch và thắt TMCT trực tiếp. Đồng thời đường mở nhĩ cần được cách xa ít nhất $1 \mathrm{~cm}$ từ rìa trên của tâm nhĩ phải. Các mũi chỉ khâu trong quá trình thay van ba lá được thực hiện xuyên qua vị trí vòng van ngoại trừ khu vực lá vách van ba lá, trong khu vực này, các mũi chỉ được được xuyên qua các mô của lá vách và các cấu trúc đi kèm để tránh nguy là block nhĩ nhất [7].

Trong phẫu thuật nội soi, việc thiết lập hệ thống tuần hoàn ngoài cơ thể qua việc đặt các ống tĩnh mạch qua da, có thể không thắt tĩnh mạch chủ trên và tĩnh mạch chủ dưới sẽ giúp hạn chế việc gỡ dính trong phẫu thuật, giảm nguy cơ can thiệp vào các vị trí dẫn truyền. Hơn nữa, với góc nhìn của camera nội soi sẽ giúp tiếp cận gần sát và chi tiết tổn thương van, mà không cần bộc lộ nhiều cũng như sử dụng những dụng cụ vén phức tạp.

Bettina Pfannmüller, Martin Misfeld và cộng sự đã thống kê trên 48 bệnh nhân thay van ba lá nội soi, tất cả các bệnh nhân đều có mổ cũ tim hở trước đó. Trong đó, đa số các bệnh nhân được thực hiện phẫu thuật thay/sửa van hai lá, các trường hợp tiền sử thay van động mạch chủ, sửa van ba lá, bắc cầu chủ vành đều có trong nghiên cứu của họ. Việc quyết định phẫu thuật nội soi cần có kết quả chụp cắt lớp vi tính ngực để đánh giá dính màng phổi phải, và nguy cơ phải gỡ dính nhiều trong mổ. Kỹ thuật thiết lập tuần hoàn ngoài cơ thể cũng được tiến hành qua các ống đặt vào động mạch đùi phải, tĩnh mạch đùi phải và tĩnh mạch cảnh trong[6].

Bệnh nhân trong trường hợp của chúng tôi là bệnh nhân lý tưởng cho lựa chọn phương pháp này. Do tiền sử mổ cũ, thể trạng gầy, việc lựa chọn một phương pháp phẫu thuật đòi hỏi giảm các nguy cơ từ phẫu thuật cưa xương ức và thời gian phẫu thuật, giảm nguy cơ gỡ dính là rất quan trọng.

Việc thực hiện để tim đập trong phẫu thuật cũng là phương thức được các phẫu thuật viên sử dụng nhiều nhất, trong nghiên cứu của Bettina Pfannmüller, Martin Misfeld, 87,5\% bệnh nhân phẫu thuật tim đập trong mổ [6]. Việc để tim đập trong mổ giúp phẫu thuật viên giảm bớt thời gian mổ cũng như vùng cần phẫu tích ở động mạch chủ, theo dõi các rối loạn nhịp trong mổ.

Khi so sánh kết quả phẫu thuật với các tác giả khác với cùng một phương pháp, chúng tôi nhận thấy kết quả của chúng tôi không khác nhiều so với họ. Theo kết quả nghiên cứu Fillip Casselman, tổng thời gian kẹp chủ và chạy tuần hoàn ngoài cơ thể là 73 và 172 phút. [5], theo Bettina Pfannmüller, Martin Misfeld thời gian chạy tuần hoàn ngoài cơ thể là khoảng 165 phút [6].Ở một nghiên cứu khác, kết quả thời gian chạy máy tim phổi nhân tạo của bệnh nhân trong mổ trung bình khoảng 150 phút [3]. Các kết quả lâm sàng và siêu âm tim sau mổ cho kết quả tốt.

Bệnh nhân của chúng tôi phải mổ lại thăm dò ngực sau mổ 5 ngày. Đây là một trong những nguy cơ sau mổ có thể gặp phải. Fillip Casselman cũng đã công bố các trường hợp chảy máu sau mổ ngực. Tuy nhiên các trường hợp đó đều không gây ảnh hưởng nhiều đến diễn biến kết quả sau mổ của bệnh nhân. [5]. Trong phẫu thuật của phương pháp này, việc gỡ dính phổi và gỡ dính tim nên được làm tối thiểu vì đây chính là một trong những nguy cơ chảy máu sau mổ.

Với việc sử dụng nội soi 3D trong mổ, chỉ cần phẫu tích gỡ dính tối thiểu là đủ để quan sát tổn thương và thực hiện các thao tác trong phẫu 
thuật. Đây là điểm mới trong phẫu thuật của chúng tôi.

\section{KẾT LUẬN}

Lựa chọn phương pháp phẫu thuật nội soi ít xâm lấn trong phẫu thuật thay van ba lá ở bệnh nhân mổ cũ thay van hai lá là lựa chọn an toàn, có kết quả phẫu thuật tốt. Trong phẫu thuật việc gỡ dính tối thiểu nắm vai trò quan trọng giúp tránh những biến chứng sau mổ thường gặp.

\section{TÀI LIỆU THAM KHẢO}

1. R. J. Moraca, M. R. Moon, J. S. Lawton, T. J. Guthrie (2009), "Outcomes of tricuspid valve repair and replacement: a propensity analysis",Ann Thorac Surg, 87(1): p. 83-88; discussion 88-89.

2. Filip P. Casselman, MD, PhD, FETCS; Mark La Meir, MD; Hughes Jeanmart, MD et al (2007), "Endoscopic Mitral and Tricuspid Valve Surgery After Previous Cardiac Surgery",Circulation ;116[suppl I]:I-270-I-275.)

3. Grossi EA, GallowayAC, Ribakove GH,
Baumann FG, Schwesinger D and Colvin SB (2001). Impact of minimally invasive valvular heart surgery: A case-control study. Ann Thorac Surg.; 71:807-810.

4. Phạm Thành Đạt, Nguyễn Công Hựu, Lê Ngọc Thành (2016). Đánh giá kết quả sớm phẫu thuật thay van hai lá ít xâm lấn qua đường mở nhỏ ngực phải có nội soi hỗ trợ tại trung tâm tim mạch bệnh viện E. Tạp chí y học Việt Nam, 10, 107-113.

5. Ranjit P. Deshpande, Filip Casselman, Anthony Vanermen et al (2006). Endoscopic redo tricuspid valve replacement in complete situs inversus.J Thorac Cardiovasc Surg, 132, 148-9.

6. Bettina Pfannmüller, Martin Misfeld, Michael A. Borger et al (2012).Isolated Reoperative Minimally Invasive TricuspidValve Operations.Ann Thorac Surg,94, 2005-10

7. Siavosh Khonsari, Colleen Flint Sintek(2007). Tricupid Surgery. Cardiac Surgery Safeguards and Pitfalls in Operative Technique. Zakow PK, Derivaux CC, 113-121. 